\title{
A Triangle-Shaped Band-pass Filter with Meander-Line Resonator and Complement Split-Ring Resonator (CSRR) Defected Ground Structure (DGS)
}

\author{
Mert Demirel $^{1 *}$, Merih Palandoken ${ }^{2}$, Esra Aycan Beyazit ${ }^{3}$ \\ 1* Izmir Katip Celebi University, Faculty of Engineering and Architecture, Departmant of Electrical and Electronics Engineering, Izmir, Turkey, (ORCID: 0000-0001- \\ 7905-8456),mdemire197@gmail.com \\ ${ }^{2}$ Izmir Katip Celebi University, Faculty of Engineering and Architecture, Departmant of Electrical and Electronics Engineering, Izmir, Turkey, (ORCID: 0000-0003- \\ 3487-2467), merih.palandoken@ikc.edu.tr \\ ${ }^{3}$ Izmir Katip Celebi University, Faculty of Engineering and Architecture, Departmant of Electrical and Electronics Engineering, Izmir, Turkey, (ORCID: 0000-0003- \\ 1035-6695), esra.aycan@ikc.edu.tr
}

(2nd International Conference on Applied Engineering and Natural Sciences ICAENS 2022, March 10-13, 2022)

(DOI: $10.31590 /$ ejosat.1082123)

ATIF/REFERENCE: Demirel, M., Palandoken, M. \& Beyazit, E. A. (2022). A Triangle-Shaped Band-pass Filter with Meander-Line Resonator and Complement Split-Ring Resonator (CSRR) Defected Ground Structure (DGS). European Journal of Science and Technology, (34), 328-331.

\begin{abstract}
A band-pass filter is a wireless component that transmits frequencies within a certain range and attenuates frequencies outside that range. Band-pass filter (BPF) has been used as a core component for an Radio Frequency (RF) communication system. BPF generally designed based on transmission line resonators. Therefore, miniaturization of these components is important. In this study, a triangleshaped band-pass filter with a meander-line resonator and complement split-ring resonator (CSRR) defected ground structure (DGS) and not defected ground structure have been propose in this study. Four different band-pass filter designs have been simulated. In addition to comparing the CSRR DGS effect in different designs, it has been tried to get better results with added perturbation. The materials and thicknesses used in the filters kept constant. BPF fabricated on a standard $\mathrm{h}$ of $1 \mathrm{~mm}$ thick Rogers RO3003 substrate with dielectric constant $\varepsilon_{\mathrm{r}}$ of 3 . It aimed to obtain better results by making only geometric changes. Making this geometric changes reliable more than one band-with ranges has been intended. Band-pass filter has been designed for $5 \mathrm{GHz}$ frequency in Wi-Fi which also has been provided considerable results for $3.2 \mathrm{GHz}$. The numerical results has been compared with the results found in this study. Compared to used sources, more efficient results has been achieved.
\end{abstract}

\section{Kıvrımlı Döngü Rezonatörlü ve Tamamlayıcı Bölünmüsş Halka Rezonatörlü (CSRR) Kusurlu Zemin Yapısına Sahip (DGS) Üçgen Şeklinde Bant Geçiren Filtre}

$\ddot{O} \mathbf{z}$

Bant geçiren filtre, belirli bir aralıktaki frekansları ileten ve bu aralığın dışındaki frekansları azaltan kablosuz bir bileşendir. Bant geçiren filtre (BPF), bir Radyo Frekansı (RF) iletişim sistemi için temel bir bileşen olarak kullanılmıştır. BF genellikle iletim hattı

* Corresponding Author: mdemire197@gmail.com 
rezonatörlerine dayalı olarak tasarlanmıştır. Bu nedenle, bu bileşenlerin minyatürleştirilmesi önemlidir. Bu çalışmada, kıvrımlı döngü rezonatörlü ve tamamlayıcı bölünmüş halka rezonatörlü (CSRR) kusurlu zemin yapısı (DGS) ve kusurlu olmayan zemin yapısına sahip üçgen şeklinde bir bant geçiren filtre önerilmiştir. Dört farklı bant geçiren filtre tasarımı simüle edilmiştir. CSRR DGS etkisinin farklı tasarımlarda karşılaştırılması yanında ilave pertürbasyon ile daha iyi sonuçlar alınmaya çalışılmıştır. Filtrelerde kullanılan malzeme ve kalınlıklar sabit tutulmuştur. Dielektrik sabiti 3 olan ve $1 \mathrm{~mm}$ kalınlığında Rogers RO3003 alt tabakası üzerinde BPF üretildi. Yalnızca geometrik değişiklikler yaparak daha iyi sonuçlar elde etmeyi amaçladı. Bu geometrik değişiklikleri birden fazla bantlı aralıkta güvenilir kılmak amaçlanmıştır. Bant geçiren filtre, Wi-Fi'de $5 \mathrm{GHz}$ frekansı için tasarlanmış olup, $3.2 \mathrm{GHz}$ için de önemli sonuçlar sağlamıştır. Sayısal sonuçlar bu çalışmada bulunan sonuçlarla karşılaştırılmıştır. Kullanılan kaynaklara göre daha verimli sonuçlara ulaşılmıştır.

Anahtar Kelimeler: band geçiren filtre, kompakt filtre tasarımı, tamamlayıcı bölünmüş halka rezonatörü, kusurlu zemin yapısı, kıvrımlı döngü rezonatörü

\section{Introduction}

Recently, wireless communication systems seeking great interest. These systems are preferred over the use of more than one single band transceiver. Until now, various tri-band band-pass filters (BPF) have been proposed for use in tri-band transceivers and were in demand. Various studies have been carried out to meet this demand. Three sets of resonators generally used for threeband BPFs. This approach causes the size of the filter to increase due to the use of a large number of resonators. Dual-mode microstrip filters have been extensively explored by a large number of researchers due to its advantages in applications needing filters with qualities such as small size, low mass, and low loss, owing to the strong desire for compact high performance in wireless communication systems [1-3].

In [4], the purpose of the article is to introduce a metamaterial inspired BPF for passband frequencies from $3.9 \mathrm{GHz}$ to $4.54 \mathrm{GHz}$. The design and operating principles have been verified by numerical and experimental results. In [5], a highly selective dualband band-pass filter with meander-loop resonators and SRR DGS has been demonstrated in this study. The two passbands created by using different resonators. Stopbands with numerous finite attenuation poles used to achieve high selectivity. The filter is smaller in size and has higher performance than a traditional dual band filter.

SRRs have been successfully applied to the fabrication of left-handed metamaterial (LHM) and the design of planar circuits. Very recently, CSRR which is the negative image of SRR has been reported by some authors [6]. It has been demonstrated that CSRR etched in the ground plane or in the conductor strip of planar transmission media provides a negative effective permittivity to the structure. CSRR has been successfully applied to the narrow band filters and diplexers with compact dimensions.

In this study, a triangle-shaped band-pass filter with a meander-line resonator has been proposed. The importance of using CSRR DGS with a proposed new design has been examined. Additionally, the rectangular perturbation size used in the design has been increased linearly and the best results evaluated in the study. The results analyzed and more complex and miniature design has been created than the designs in other articles.

\section{Material and Method}

In this section, the filter design is introduced. The geometric parameters have been stated in Figure 2. The substrate size has been selected to be $30 \times 30 \mathrm{~mm}^{2}$. The proposed BPF has been fabricated on a standard $1 \mathrm{~mm}$ thick Rogers RO3003 substrate with dielectric constant $\varepsilon$ of 3 . The total filter size $(\mathrm{W} \times \mathrm{L})$ is 30 $\times 30 \mathrm{~mm}^{2}$. The filter design has been modeled with the CST Studio Suite program. Filter design consists of three stages. First, the typical filter with meander-loop resonator has been structured. No changes have been done to the ground part in this part.

\subsection{Band-pass Filter without CSRR DGS}

In the first design, the topology of CSRR DGS is shown in Figure 2 and Figure 5. The simulation results are given in Figure 1. A deduced numerical calculation result, a band-pass filter with two bands has been obtained. According to the results, it has been observed that the $\mathrm{S} 21$ value is $-0.82 \mathrm{~dB}$ at $3.24 \mathrm{GHz}$ and $-2.14 \mathrm{~dB}$ at $5.92 \mathrm{GHz}$.

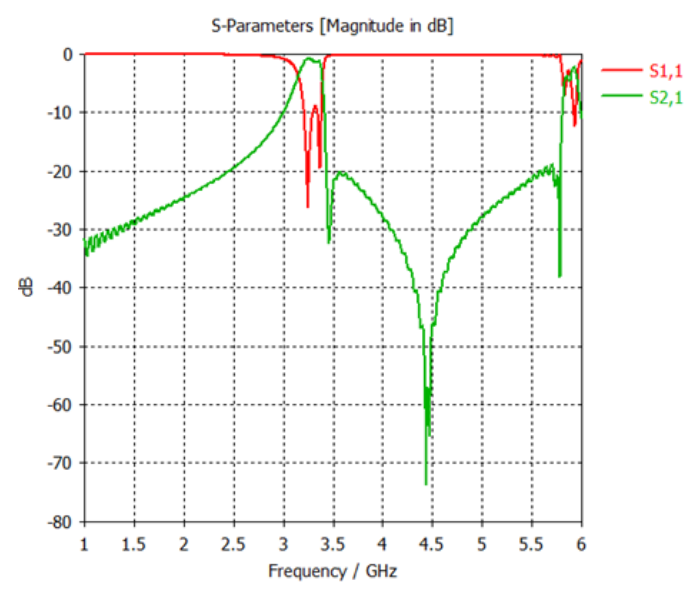

Fig. 1 Numerical Calculation Results without CSRR DGS

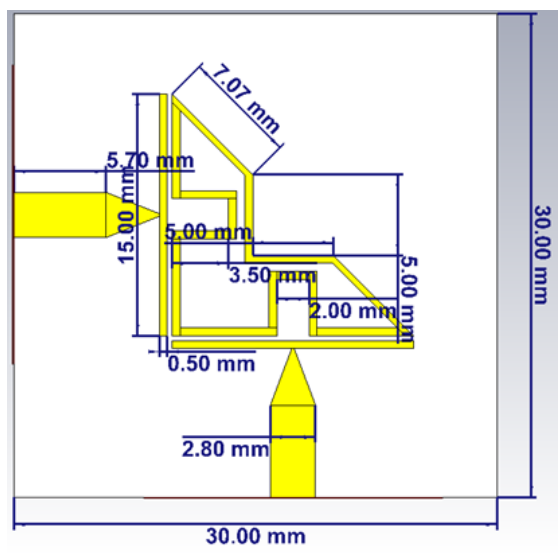

Fig. 2 Band-pass Filter Design Top Side 


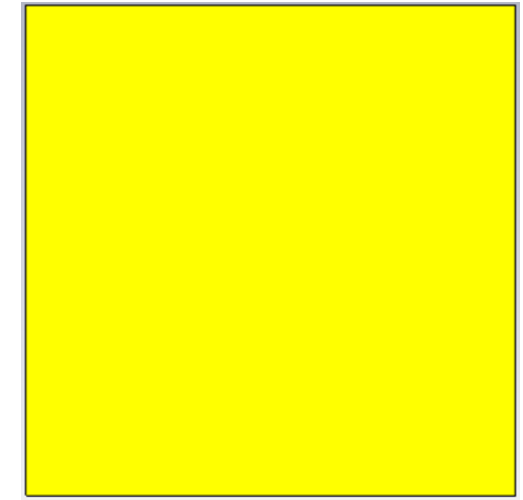

Fig. 3 Band-pass Filter Design Bottom Side without CSRR DGS

\subsection{Band-pass Filter with CSRR DGS}

Park et al. introduced DGS in 1999, based on the notion of photonic band-gap (PBG) structure, and it has been used in the design of planar circuits and low-pass filters [7]. DGS has been achieved by etching a faulty pattern in the ground plane [8], which disrupts the ground plane's shield current distribution. The slowwave effect and band-stop property may be obtained by changing the properties of a transmission line, such as equivalent capacitance and inductance.

In the second design, CSRR DGS added to the design and simulation results have been obtained. The topology of CSRR DGS shown in Figure 2 and Figure 5. A deduced numerical calculation result, a band-pass filter with three bands has been obtained. According to the results, it has been observed that the $\mathrm{S} 21$ value is $-1.98 \mathrm{~dB}$ at $1.91 \mathrm{GHz},-1.8 \mathrm{~dB}$ at $3.19 \mathrm{GHz}$ and -1.55 $\mathrm{dB}$ at $5.46 \mathrm{GHz}$ in Figure 4.

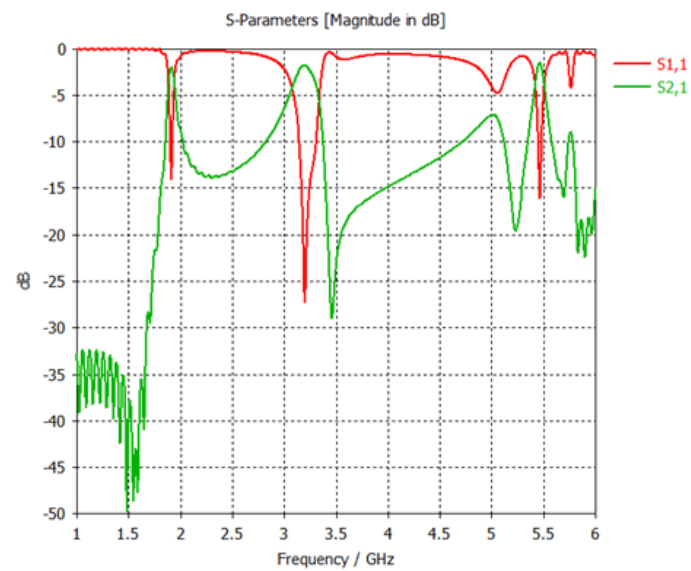

Fig. 4 Numerical Calculation Results with CSRR DGS

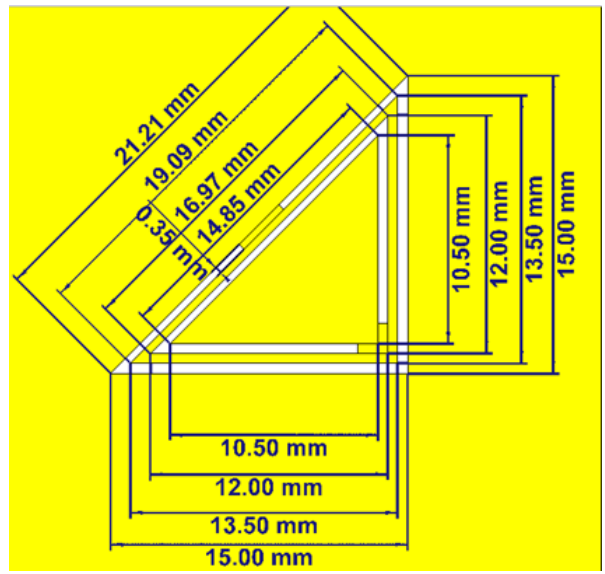

Fig. 5 Band-pass Filter Design Bottom Side with CSRR DGS

\subsection{Best Performance Band-pass Filter with Perturbation but without CSRR DGS}

In the third design, the topology of CSRR DGS has been shown in Figure 3 and Figure 7. As deduced from numerical calculation result, a band-pass filter with two bands has been obtained. According to the results, it has been observed that the $\mathrm{S} 21$ value is $-1.02 \mathrm{~dB}$ at $3.2 \mathrm{GHz}$ and $-0.56 \mathrm{~dB}$ at $5.8 \mathrm{GHz}$ in Figure 6.

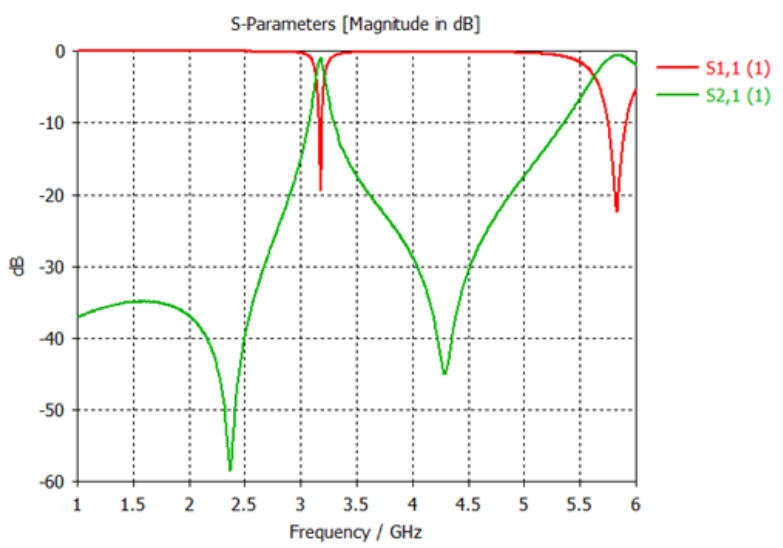

Fig. 6 Numerical Calculation Results without CSRR DGS in ground plane

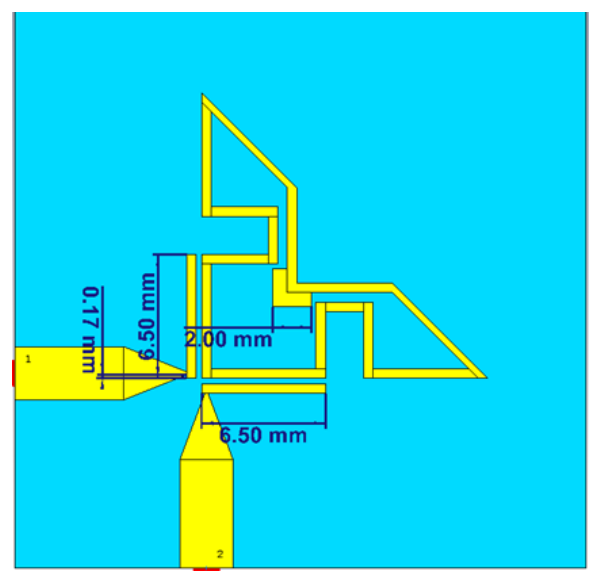

Fig. 7 Band-pass Filter Design Top Side without CSRR DGS in ground plane 


\subsection{Best Performance Band-pass Filter with Perturbation and CSRR DGS}

In the fourth design, the topology of CSRR DGS has been shown in Figure 5 and Figure 7. A deduced numerical calculation result, a band-pass filter with two bands has been obtained. According to the results, it has been observed that the $\mathrm{S} 21$ value is $-1.14 \mathrm{~dB}$ at $3.14 \mathrm{GHz}$ and $-1.06 \mathrm{~dB}$ at $5.7 \mathrm{GHz}$ in Figure 8.

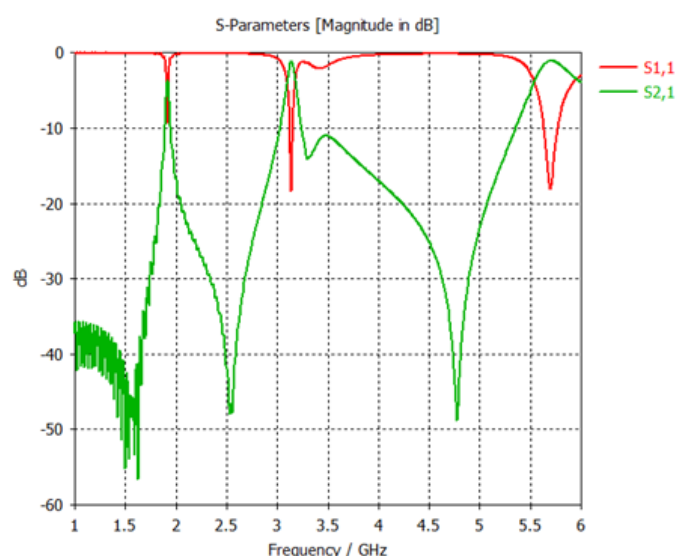

Fig. 8 Numerical Calculation Results CSRR DGS in ground plane

\section{Results and Discussion}

In the previous section, four different design results have been given respectively. When the results have been examined, the best result has been observed in the third filter. Considering S21 values, the level of $-0.56 \mathrm{~dB}$ is obtained at $5.8 \mathrm{GHz}$.

Although the CSRR DGS structure is less efficient, this process on the ground has resulted to obtain an extra band without any change in the resonator structure. In addition, much better results have been obtained at similar frequencies with added perturbation. Shifting the positions of the lines coming from the ports has also an effect.

$5.8 \mathrm{GHz}$ band offers more bandwidth, and because it operates at a higher frequency, equipment prices are slightly higher, but utilization and hence interference are lower. It is compatible with 802.11a and $\mathrm{n}$ wireless networks. It has a shorter range than 2.4 $\mathrm{GHz}$ and can carry up to 23 non-overlapping channels. Many wireless technology suppliers choose $5.8 \mathrm{GHz}$ Wi-Fi because of the quantity of channels and bandwidth offered. When the results are analyzed, a design that can be used in the Wi-Fi band and has good performance as suggested. It has been observed that it has a better result than the values obtained in other articles.

\section{Conclusions and Recommendations}

In this study, two different band-pass filter circuit topologies based on a triangle-shaped structural form including a meanderline resonator with CSRR DGS and without DGS has been proposed. Best band-pass filter has been designed with the perturbation in the resonator geometry without DGS. As a result of numerical computations, a band-pass filter design has been proposed for $5 \mathrm{GHz}$ frequency in Wi-Fi. It also gave good results in the other band $3.2 \mathrm{GHz}$. The numerical computations has given better results than the designs conducted with the traditional methods.

\section{References}

[1] Palandöken, Merih, and Adnan Sondas. "Compact Metamaterial Based Bandstop Filter." Microwave Journal 57.10 (2014)

[2] Palandoken, M., and H. Henke. "Fractal spiral resonator as magnetic metamaterial." 2009 Applied Electromagnetics Conference (AEMC). IEEE, 2009.

[3] Palandoken, Merih. "Metamaterial-Based Compact Filter Design." Metamaterial. IntechOpen, 2012.

[4] Palandöken, M., \& Ucar, M. H. (2014). Compact metamaterial-inspired band-pass filter. Microwave and Optical Technology Letters, 56(12), 2903-2907.

[5] Ozkaya, U., \& Seyfi, L. (2015). Dimension optimization of microstrip patch antenna in $\mathrm{X} / \mathrm{Ku}$ band via artificial neural network. Procedia-Social and Behavioral Sciences, 195, 2520-2526.

[6] Wu,B.,B. Li,T. Su,and C.-H. Liang, "Equivalent-circuit analysis and lowpass filter design of spit-ring resonator DGS," Journal of Electromagnetic Waves and Applications,Vol. 20,No. 14,1943-1943,2006.

[7] Bonache,J.,I. Gil,J. Garcia-Garcia,and F. Martin, "Novel microstrip band-pass filters based on complementary splitring resonators," IEEE Trans. Microwave Theory Tech., Vol. $54,265-271,2006$.

[8] Bonache,J. and I. Gil,J. Garcia-Garcia,and F. Martin, "Complementary split ring resonators for microstrip diplexer design,” Electron. Lett.,Vol. 41,20 